\title{
INVENTARISASI SERANGGA PENYERBUK, HAMA DAN PENYAKIT DOMINAN PADA AREN
}

\author{
Ameilia Zuliyanti Siregar \\ Departemen Agroekoteknologi Fakultas Pertanian USU \\ *Corresponding author:azsyanti@gmail.com
}

\begin{abstract}
ABSTRAK
Tanaman aren (Arenga pinnata Merr) dalam pertumbuhannya tergantung pada bibit, tipe tanah, kesesuaian lahan, faktor lingkungan, serta keberadaan serangga (terutama serangga penyerbuk) seperti lebah madu dan cocopet. Hama-hama dan penyakit pada tanaman aren diinventarisasi dari jenis Oryctes rhinoceros, Rhynchoporus sp, Sexava sp, Artona sp, dan kelelawar yang mendominasi pada pertanaman aren di Indonesia. Jenis penyakit yang sering menyerang pohon aren di persemaian adalah bercak dan kuning pada daun yang disebabkan oleh Pestalotia sp., Helmiathosporus sp. Pengendalian hama tanaman aren dapat dilakukan dengan pengendalian mekanik, kimia dan biologi. Aren sebagai sumber daya pangan daerah tropis memiliki berbagai manfaat bagi masyarakat sebagai sumber pangan (kolang-kaling, gula merah, pati tepung, cuka, nira, bioetanol), akar untuk obat tradisional, bahan kerajinan tangan, keranjang, atap rumah serta daun muda/janur untuk pembungkus kertas rokok.
\end{abstract}

Kata Kunci: Studi, Pustaka, Serangga Penyerbuk, Hama, Penyakit, Aren

\begin{abstract}
Plant sugar palm (Arenga pinnata Merr) in its growth depends on seeds, soil types, land suitability, environmental factors, as well as the presence of insects (especially insect pollinators) such as honeybees and earwig. Pests and diseases in the sugar plant of the type of Oryctes rhinoceros inventoried, Rhynchoporus sp, sp Sexava sp, Artona sp, and bats which dominates in palm plantations in Indonesia. Types of diseases that often attack the palm trees in the nursery is spotting and yellow in the leaves caused by Pestalotia sp., Helmiathosporus sp. Palm plants pest control can be done by controlling the mechanical, chemical and biological. Aren as food resources of the tropics has many benefits for the community as a source of food (to and fro, brown sugar, starch, vinegar, juice, bioethanol), roots for traditional medicine, materials crafts, baskets, roofs and young leaves / leaf for cigarette paper wrappers.
\end{abstract}

Keywords: Study, Library, insect pollinators, pests, diseases, Aren.

\section{PENDAHULUAN}

Tanaman aren (Arenga pinnata Merr) adalah tanaman perkebunan yang sangat potensial dalam hal mengatasi kekurangan pangan dan mudah beradaptasi baik pada berbagai agroklimat, mulai dari dataran rendah sehingga $1400 \mathrm{~m}$ di atas permukaan laut Pengusahaan tanaman aren sebagian besar diusahakan oleh petani dan belum diusahakan dalam skala besar, karena pengelolaan tanaman belum menerapkan teknik budidaya yang baik menyebabkan produktivitas pertanaman rendah. Saat ini produk utama tanaman aren adalah nira hasil penyadapan dari bunga jantan yang dijadikan gula aren maupun minuman ringan, cuka dan alkohol Selain itu tanaman aren dapat menghasilkan produk makanan seperti kolang kaling dari buah betina yang sudah masak dan 
tepung aren untuk bahan makanan dalam bentuk kue, roti dan biskuit yang berasal dari pengolahan bagian empelur batang tanaman (Alam dan Baco, 2004; Maliangkay et al., 2004).

Pohon aren termasuk suku palempaleman yang memiliki berbagai fungsi antara lain fungsi konservasi dan fungsi ekonomis, sebab hampir semua bagian tanaman akar, batang, daun, buah dapat dimanfaatkan untuk berbagai keperluan manusia. Sampai dengan akhir tahun 1980-an, budidaya intensif pembibitan aren belum terlalu dikenal, perbanyakan dan penyebarannya terjadi secara alamiah, dilakukan melalui semaian alami atau disebarkan oleh musang (di Pulau Jawa). Setelah tahun 1990-an, melalui Kebun Raya Bogor (KRB) mulai dikembangkan tehnik-tehnik silvikultur baru dalam budidaya aren (Lasut, 2012).

Saat ini populasi aren di alam semakin berkurang. Hal ini disebabkan banyaknya pohon yang sudah tua, sehingga tidak produktif lagi, sedangkan upaya peremajaan populasi aren belum dilakukan secara maksimal. Banyaknya masyarakat yang memanfaatkan aren untuk kegiatan industri rumah tangga, tanpa adanya upaya peremajaan dikhawatirkan akan menyebabkan populasi aren tersebut semakin terancam dalam penyebaran aren. Di Sumatera, misalnya tanaman aren ditemukan di Buluh Awar, Kab. Sibolangit, Kab. Deli Serdang, Desa Petatal, Lima Puluh, Batubara, sedangkan masyarakat Desa Rancakalong sangat mengandalkan jasa dari alam (regenerasi alam) yaitu melalui peranan musang (Paradoxurus hermaphroditus). Dimana musang memakan buah aren yang sudah matang. Buah aren yang dimakan oleh musang bijinya tidak hancur, tetapi terbawa keluar bersama kotorannya. Biji inilah yang sering mudah berkecambah dan tumbuh secara liar menjadi aren, hancur, tetapi terbawa keluar bersama kotorannya (Mujahidin,dkk,2003).

Pengolahan data yang dikeluarkan Ditjenbun tahun 2003 dan estimasi laju perkembangan areal beberapa provinsi yang mengusahakan tanaman aren, total areal yang telah ditanami di seluruh Indonesia mencapai 60.482 ha dengan produksi gula aren sebesar 30.376 ton/tahun. Areal dan produksi gula yang terbesar terdapat pada provinsiprovinsi Jawa Barat 13.135 ha dengan produksi 6.686 ton gula/tahun, Papua 10.000 ha dengan 2.000 ton gula/tahun, Sulawesi Selatan 7.293 ha dengan produksi 3,174 ton gula/tahun, dan Sulawesi Utara 6.000 ha dengan produksi 3.000 ton gula/ha. Tanaman aren karena memiliki daya adaptasi terhadap berbagai kondisi lahan, agroklimat, dan toleransi tinggi dalam pola pertanaman campuran termasuk dengan tanaman berkayu serta cepat bertumbuh karena memiliki akar banyak dan tajuk lebat sangat cocok untuk dikembangkan juga pada lahan-lahan marginal yang kebanyakan dimiliki petani miskin. Untuk mengatasi peningkatan luas dan jumlah kawasan lahan miskin di Indonesia dengan laju yang semakin tinggi diperlukan tipe tanaman seperti tanaman aren. Tanaman ini memberikan produksi nira yang layak diusahakan dengan input rendah dan sangat cocok untuk tujuan konservasi air dan tanah. Di samping itu, tanaman aren menghasilkan biomas di atas tanah dan dalam tanah yang sangat besar sehingga berperan penting dalam siklus $\mathrm{CO}_{2}$ (Syakir dan Effendi, 2010).

\section{Manfaat}

Manfaat dari studi pustaka ini untuk menginventarisasi serangga penyerbuk dan hama-hama dominan pada tanaman aren serta sebagai informasi bagi para petani aren

\section{DESKRIPSI TANAMAN AREN}

Tanaman aren menurut klasifikasi tanaman dimasukkan dalam divisi Spermatophyta, subdivisi Angiospermae, kelas Monocotyledonae, bangsa Spadicitlorae, suku Palmae, marga Arenga dan jenis Arenga pinnata MERR. Tanaman ini tumbuh pada beberapa daerah dengan nama berbeda, seperti di Aceh disebut Bakjuk, Batak Karo diberi nama Paula, Nias diberi nama Peto, Minangkabau dengan Biluluk, Lampung disebut Hanau, Jawa Tengah diberi nama Aren, Madura menyebutnya Are dan di Bali 
nama Hano. Tenggara diberi nama: Jenaka, Pola, Nao, Karodi, Moka, Make, Bale dan Bone. Pemberian nama tanaman ini untuk Sulawesi: Apele, Naola, Puarin, Onau, dan Inau. Sedangkan untuk kepulauan Maluku diberi nama: Seko, Siho, Tuna, Nawa dan Roni. (Rindengan dan Manaroinsong, 2009).

Berdasarkan habitus tanaman; pohon aren berdiri tegak dan tinggi, berbatang bulat warna hijau kecoklatan, daun terbentuk dalam reset batang dengan anak daun menyirip berwarna hijau muda/tua, bunga terdiri atas bunga jantan yang menyatu dalam satu tongkol ukuran panjang $1-1,2 \mathrm{~cm}$. Bunga betina pada tongkol yang lain bentuk bulat yang terdiri atas bakal buah tiga buah, warna kuning keputihan. Buah yang telah terbentuk berbentuk bulat panjang dengan ujung melengkung ke dalam, diameter 3-5 cm. Di dalam buah terdapat biji yang berbentuk bulat dan apabila sudah matang warna hitam. Pohon aren akan mencapai tingkat kematangan pada umur 6-12 tahun. Kondisi penyadapan terbaik pada umur 8-9 tahun saat mayang bunga sudah keluar. Penyadapan dapat dilakukan pagi dan sore, setiap tahun dapat disadap 3-12 tangkai bunga dengan hasil rata-rata 6,7 liter/hari atau sekitar 9001600 liter/pohon/tahun. Kualitas nira terbaik bila kadar sukrosa tinggi. (Balitka, 1992).

Menurut Effendi (2009), tanaman aren dapat tumbuh dengan baik di dekat pantai sampai pada dataran tinggi $1200 \mathrm{~m}$ dari permukaan laut. Tanaman aren sangat cocok pada kondisi landai dengan kondisi agroklimat beragam seperti daerah pegunungan dimana curah hujan tinggi dengan tanah bertekstur liat berpasir. Dalam pertumbuhan tanaman ini membutuhkan kisaran suhu $20-25^{\circ} \mathrm{C}$, terutama untuk mendorong perkembangan generatif agar dapat berbunga dan berbuah. Sedang untuk pembentukan mahkota tanaman, kelembaban tanah dan ketersediaan air sangat diperlukan dimana curah hujan yang dibutuhkan antara 1200-3500 mm/tahun agar kelembaban tanah dapat dipertahankan.

\section{DISTRIBUSI TANAMAN AREN}

Pada tahun 2003 total areal tanaman ini tercatat seluas 49.758 ha dengan produksi 29.174 ton gula (Ditjenbun, 2004). Berdasarkan data yang ada areal tanaman aren bertambah 2,0 \% per tahun sedangkan produksi meningkat sebesar $1,9 \%$ per tahun. Menurut Rumokoi (2004) data ini perlu diverifikasi karena aren sebagian besar belum dibudidayakan dan penambahan areal baru belum ada kejelasan. Hasil survei Manoi dan Wardiana (1990) di Jawa Barat untuk kategori tanaman menghasilkan jumlahnya menurun rata-rata pertahun $1,76 \%$, tanaman belum menghasilkan meningkat $4,7 \%$, Sedang tanaman tua/rusak meningkat tajam 20,8\%. Dilihat dari jumlah yang ada, proporsi tanaman menghasilkan 54\%, tanaman belum menghasilkan $40 \%$, dan tanaman tua/rusak 6\% memperjelas bahwa areal tanaman aren yang ada di daerah ini sekitar 13.135 ha tidak bertambah bahkan menurun sejak tahun 1980 . Data perkiraan luas tanaman aren saat ini kurang tepat jika menggunakan hanya luas areal. Sebab antar petani di setiap daerah tidak sama kepadatan per hektar. Di Sumatera kepadatan tanaman 5-164 pohon/ha, di Sulawesi Utara menurut Kindangen et al. (1991), 3-120 pohon/ha, sedang di Papua 7-75 pohon/ha (Akuba, 1993). Kepadatan populasi tanaman aren sebaiknya dilakukan berdasarkan data jumlah populasi aren. Umumnya tanaman aren banyak yang tumbuh di kawasan hutan sehingga populasi aren dapat dilakukan dengan menghitung luas kawasan hutan dikali dengan kepadatan populasi aren. Berdasarkan data yang dikeluarkan Ditjenbun pada tahun 2003 dan estimasi berdasarkan laju perkembangan areal sejak 1990. Aren (Arenga pinnata Merr) merupakan salah satu sumber daya alam di daerah tropis, distribusinya tersebar luas, sangat diperlukan dan mudah didapatkan untuk keperluan sehari-hari oleh masyarakat setempat sebagai sumber daya yang berkesinambungan. Di Indonesia pohon aren sebagian besar secara nyata digunakan untuk bahan bangunan, keranjang, kerajinan tangan, atap rumah, gula, manisan buah dan lain 
sebagainya. Aren merupakan tumbuhan serbaguna, dimana setiap bagian pohon aren tersebut dapat diambil manfaatnya, mulai dari akar untuk obat tradisional, batang untuk berbagai macam peralatan dan bangunan, daun muda/janur untuk pembungkus kertas rokok. Hasil produksinya juga dapat dimanfaatkan, misalnya buah aren muda diolah menjadi kolang-kaling, air nira untuk bahan pembuatan gula merah/cuka dan pati/tepung dalam batang untuk bahan pembuatan berbagai macam makanan (Juanda, 2005).

Tabel 1. Perkiraan luas tanaman aren di Indonesia

\begin{tabular}{clc}
\hline No & Propinsi Perkiraan & . Total Area (ha) \\
\hline 1 & NAD & 4.081 \\
2 & Sumatera Utara & 4.357 \\
3 & Sumatera Barat & 1.830 \\
4 & Bengkulu & 1.74 \\
5 & Jawa Barat & 13.135 \\
6 & Banten & 1.448 \\
7 & Jawa Tengah & 3.078 \\
8 & Kalimantan Selatan & 1.442 \\
9 & Sulawesi Utara & 6.000 \\
10 & Sulawesi Selatan & 7.293 \\
11 & Sulawesi Tenggara & 3.070 \\
12 & Maluku & 1.000 \\
13 & Maluku Utara & 2.000 \\
14 & Papua & 10.000 \\
\hline & Total & 60.482 \\
\hline
\end{tabular}

Sumber : Akuba (2004)

Secara umum suatu keberhasilan pengembangan pertanaman ditentukan oleh lingkungan dimana komoditas itu dikembangkan. Agroekosistem atau faktor biofisik seperti tanah dan iklim menjadi peluang atau kendala dalam pembangunan komoditas tersebut. Keberhasilan pembangunan pertanian sangat tergantung pada kemampuan petani atau pelaku agribisnis menerapkan teknologi yang ada dengan memanfaatkan sumberdaya alam. Indonesia memiliki sumberdaya lahan yang luas untuk pengembangan komoditas pertanian. Dari luas daratan 188,20 juta ha yang terdiri atas 148 juta ha lahan kering dan 40,20 juta lahan basah memungkinkan untuk pengusahaan berbagai tanaman termasuk tanaman penghasil biofuel seperti bioetanol (Departemen Pertanian, 2006).

Dalam mendukung perkembangan aren, ada bebarapa faktor yang mempengaruhi pertumbuhan,seperti ketersediaan bibit, tipe tanah, lahan dengan kontour yang sesuai, serta keberadaan serangga (terutama serangga penyerbuk) seperti lebah madu dan cocopet pada pertanaman aren. Serangga penyerbuk adalah hama dan penyakit tanaman aren sampai saat ini belum banyak diketahui. Hal ini disebabkan oleh belum dibudidayakannya tanaman aren secara intensif oleh masyarakat sehingga belum ada perhatian khusus terhadap perawatan tanaman aren.

Banyak jenis serangga yang berasosiasi dengan bunga kelapa ada yang berperan sebagai hama, musuh alami, dan penyerbuk. Penyerbukan adalah faktor terpenting dalam pertumbuhan buah dan bijibijian, sebagai syarat dalam produksi buah. Penyerbukan merupakan pelayanan ekosistim yang sangat penting disebabkan 35\% dari tanaman pensuplai pangan di bumi membutuhkan media lain sebagai penyerbuk. Di negara-negara yang maju industri perlebahannya, tujuan utama budidaya lebah madu bukan semata-mata untuk memanen madu, melainkan mengharapkan peran lebah 
madu sebagai polinator. Sebagai contoh, sekitar 95\% dari 3 juta koloni lebah madu yang dibudidayakan di Amerika Serikat bertujuan untuk memanfaatkan lebah sebagai polinator dan sisanya untuk menghasilkan madu. Kini, tidak kurang 30\% produk pangan asal tanaman yang dihasilkan di Amerika Serikat, proses penyerbukannya dibantu oleh lebah madu (Salim dan Rahma, 2012).

Hama kumbang badak, Oryctes rhinoceros dan Rhinochophorus ferrugineus (kumbang sagu) serta belalang (Sexava spp) menyerang pucuk pohon sampai masuk kedalam batang atas dan menembus pangkal pelepah daun muda. Selain itu hama penggerek daun muda Artona sp adalah hama penting pada tanaman aren. Hama lain untuk pohon aren ini adalah pengisap nira dan bunga seperti lebah dan kelelawar (Effendi, 2010). Jenis penyakit yang sering menyerang pohon aren di persemaian adalah bercak dan kuning pada daun yang disebabkan oleh Pestalotia sp., Helmiathosporus sp (Lasut, 2012).

Untuk menjamin ketersediaan aren sebagai bahan pangan dan penghasil bioetanol dalam jumlah yang cukup secara berkelanjutan diperlukan perluasan tanaman aren ke lahan-lahan yang belum dimanfaatkan secara optimal termasuk lahan-lahan kritis. Sehubungan dengan perluasan tersebut, sumber benih dapat diambil dari seleksi pohon induk yang berasal dari blok-blok penghasil tinggi nira. salah satu bahan bakar yang dapat digunakan mengganti bensin adalah etanol. Etanol sering disebut etil alcohol dengan rumus kimia $\mathrm{C} 2 \mathrm{H} 5 \mathrm{OH}$, bersifat cair pada temperatur kamar. Dari hasil penelitian BNDES dan CGEE (2008) penggunaan etanol sebagai bahan bakar dalam mesin dapat dilakukan dalam dua cara: (1) bensin dicampur dengan anhydrous ethanol atau (2) etanol murni yang bersifat hidrasi (Handayani, 2010).

\section{SERANGGA PENYERBUK TANAMAN AREN}

Polinator sangat diperlukan terutama pada tanaman yang tidak bisa melakukan penyerbukan sendiri. Polinator dikategorikan dalam dua kelompok yaitu polinator abiotik dan biotik. Polinator abiotik meliputi angin, air, dan gravitasi. Polinator biotik yaitu penyerbukan dengan bantuan makhluk hidup seperti serangga (Salim et al., 2012). Aphis spp (lebah madu) (Salim, Cocopet memangsa hama Tirathaba sp. pada bunga kelapa dengan populasi cocopet $\geq 80$ ekor per tandan. Polen yang terbawa oleh seekor cocopet rata-rata $55.7 \pm 37.6$ polen. Cocopet selain predator, juga sebagai pollinator (Rahma dan Salim, 2015).

\section{HAMA- HAMA TANAMAN AREN}

Hama tanaman aren yang utama, seperti Oryctes rhinoceros dan Rhynchoporus sp menyerang pucuk pohon sampai masuk kedalam batang atas dan menembus pangkal pelepah daun muda. Jaringan muda digerek, cairannya diisap. Pada daun bekas gerekan terlihat seperti terpotongpotong. Pengendalian secara mekanik dengan menebang pohon, kemudian dibakar. Pengendalian secara kimia, pada pucuk pohon diberi Heptachlor sebanyak 10 gram. Pengendalian secara biologi dengan menggunakan cendawan Metarhizium anisopliae yang dapat menyerang tanaman aren. Selain itu hama penting penggerek daun muda Artona sp dapat dikendalikan secara mekanis dilakukan dengan memangkas daundaun yang terserang. Pengendalian secara biologi dapat dilakukan dengan menggunakan parasit Apanteles artonae. Sedangkan secara kimia dapat digunakan Arcotine D-25 EC dengan dosis 0,25 gram pertanaman atau dengan racun kontak lainnya. Hama lain untuk pohon aren ini adalah pengisap nira dan bunga seperti lebah dan kelelawar (Effendi, 2010).

Penyakit tanaman aren sering disebabkan oleh cendawan Helminthosporium sp. Akibat serangannya daun cepat mengering sehingga mempengaruhi pertumbuhan bibit. Pada permukaan daun yang masih muda bagian atas dan bawah daun muncul bercakbercak kecil berwarna hijau mengkilat yang selanjutnya membesar dan berubah warna menjadi coklat dengan bagian tepi terdapat lingkaran kuning. 
Tabel 2. Rataan polen terbawa oleh Cocopet

\begin{tabular}{clc}
\hline Pohon & Propinsi Perkiraan & $\begin{array}{c}\text {. Rata-rata } \\
\text { polen/Cocopet }\end{array}$ \\
\hline 1 & $\geq 80$ & 59 \\
2 & $\geq 80$ & 52.8 \\
3 & $\geq 80$ & 60.3 \\
4 & $\geq 80$ & 55.7 \\
5 & $\geq 80$ & 51.2 \\
6 & $\geq 80$ & 74.2 \\
7 & $\geq 80$ & 63.2 \\
8 & $\geq 80$ & 38.8 \\
9 & $\geq 80$ & 47 \\
10 & $\geq 80$ & 54.8 \\
\hline & Rata-rata \pm SD & $55.7 \pm 37.6$ \\
\hline
\end{tabular}

Penyakit lainnya yang sering menyerang tanaman aren disebabkan oleh cendawan Pestalotiopsis palvarium dan pada pembibitan ditemukan bersama Helminthosporium sehingga dapat mematikan bibit aren. Gejala serangannya pada permukaan daun yang agak tua, bagian bawah daun dan atas terlihat bercakbercak membesar berukuran diameter 2-3 cm berwarna kuning keputih-putihan dan ditengahnya terdapat bintik-bintik berwarna hitam. Pengendalian dapat dilakukan dengan menggunakan pupuk yang mengandung Chlorine $(\mathrm{KCl}, \mathrm{NaCl}=$ garam dapur). Dianjurkan untuk tidak terlalu banyak menggunakan pupuk $\mathrm{N}$, karena mudah terserang penyakit bercak daun ini. Penanggulangan penyakit ini dapat dilakukan dengan fungisida seperti Dithane N-45, Delsene NX 200, atau Antracol (Effendi, 2010; Lasut,2012).

Pada batang aren umumnya serangan penyakit ini disebabkan oleh cendawan Ceratocyctis paradoxa. Gejala serangannya pada tandan buah, bunga tampak mulai membusuk. Pelepah daun dapat juga membusuk dan mengering. Daun muda yang muncul kemudian akan mengering dan menjalar ke daun-daun yang lebih tua sehingga tanaman akhirnya akan mati. Selain penyakit-penyakit diatas tanaman diserang juga oleh cendawan Fusarium oxysporum. Gejala terjadi pada saat daun muda belum membuka. Setelah daun daun membuka, akan tampak adanya bulatan-bulatan oval. Berwarna kuning pucat mengelilingi warna coklat. Bagianbagian tersebut kemudian mengering. Penyakit ini menyerang bibit dan tanaman muda di lapang (Effendi, 2010).

\section{SIMPULAN}

Pertumbuhan tanaman aren (Arenga pinnata Merr) ditentukan oleh bibit, tipe tanah, lahan dengan kontour yang sesuai, faktor lingkungan, serta keberadaan serangga (terutama serangga penyerbuk) seperti lebah madu dan cocopet. Hama-hama dan penyakit pada tanaman aren diinventarisasi dari jenis Oryctes rhinoceros, Rhynchoporus sp, Sexava $\mathrm{sp}$, Artona sp, dan kelelawar. Jenis penyakit yang sering menyerang pohon aren di persemaian adalah bercak dan kuning pada daun yang disebabkan oleh Pestalotia sp., Helmiathosporus sp. Pengendalian hama tanaman aren dapat dilakukan dengan pengendalian mekanik, kimia dan biologi. Aren sebagai sumber daya pangan daerah tropis memiliki berbagai manfaat bagi masyarakat sebagai sumber pangan (kolang- 
kaling, gula merah, pati tepung, cuka, nira, bioetanol), akar untuk obat tradisional, bahan kerajinan tangan, keranjang, atap rumah serta daun muda/janur untuk pembungkus kertas rokok.

\section{DAFTAR PUSTAKA}

Alam dan Baco. 2004. Peluang Pengembangan dan Pemanfaatan Tanaman Aren di Sulawesi Selatan. Pengembangan Tanaman Aren. Prosiding Seminar Nasional Aren. Tondano. Balai Penelitian Tanaman Kelapa dan Palma Lain. hlm.15-21.

Balitka. 1992. Prospek Tanaman Kelapa, Aren, Lontar dan Gewang Untuk Menghasilkan Gula. Media Komunikasi Penelitian dan Pengembangan Tanaman Industri. hlm. 37-40.

Departemen Pertanian. 2006. Kebijakan penyediaan bahan baku biofuel dan prospek pengembangan tanaman aren mendukung kebutuhan bioetanol di Indonesia (Dedi Soleh Effendi). Makalah Disampaikan Pada Seminar Bioenergi Prospek Bisnis dan Peluang Investasi. Badan Pengkajian dan Penerapan Teknologi. 6 Desember 2006, Jakarta.

Effendi,S.,D.2010.Prospek pengembangan tanaman aren (Arenga piñata Merr) mendukung kebutuhan bioethanol Indonesia. Pusat Penelitian dan Pengembangan Perkebunan.Bogor.

Effendi, D.S. 2009. Aren, Sumber Energi Alternatif. Warta Penelitian dan Pengembangan Pertanian 31(2):1-3.

Handayani, S.R. 2010. Pemanfaatan Bio Ethanol Sebagai Bahan Bakar Pengganti Bensin. Hlm. 99-102. http://blog.its.ac.id/arifinbits/files/2008/ 12 /pemanfaatan-bio-ethanol.pdf. Diakses pada tanggal 15 Maret 2010.

Juanda, J. 2005. Studi Etnobotani Kayu Angin (Usnea spp.) di Kabupaten Garut Jawa Barat. Skripsi. Jurusan Biologi FMIPA Unpad, Bandung.

Kindangen, J.G., Jefri, N.M. Mokodongan dan H. Hasni. 1991. Potensi dan
Sebaran Tanaman Aren di Sulawesi Utara. Buletin Balitka 14: 83-89.

Lasut,T.,M.2012.Budidaya yang baik aren (Arenga piñata Merr). Fakultas pertanian universitas samratulangi dan Universitas Texas A\&M.

Maliangkay, R.B., Yulianus Matana, Novalisa Lumentut, dan E. Manaroinsong. 2004. Budidaya Tanaman Aren. Pengembangan Tanaman Aren. Prosiding Seminar Nasional Aren Tondano, 9 Juni 2004. Balai Penelitian Tanaman Kelapa dan Palma Lain. hlm.131-137.

Manoi dan Wardiana.1990. Perkembangan Luas Areal dan Poduksi Gula Aren di Jawa Barat. Buletin Balitka 11. hlm 92 $-96$.

Mujahidin,. Sutrisno,. Dian, L,. Tri, H. dan Izu, A. F. 2003. Aren Budidaya dan Prospeknya. Bogor : Pusat Konservasi Tumbuhan Kebun Raya Bogor-LIPI.

Rahma dan Salim. 2015. Cocopet Sebagai Predator dan Pollinator Pada Tanaman Kelapa. Prosiding Konferensi Nasional Kelapa VIII. Balai Peneliian Tanaman Palma, Menado. 193-198.

Rindengan, B dan E.Manaroinsong. 2009. Aren. Tanaman Perkebunan Penghasil Bahan Bakar Nabati (BBM). Pusat penelitian dan Pengembangan Perkebunan. hlm.1-22.

Salim, D. Novianti dan Rahma. 2012. Serangga-serangga polinator pada tanaman aren (Arenga pinnata Merr). Prosiding aren untuk pangan dan alternatif energi terbarukan. Balikpapan, 26-27 September 2012. 214-219.

Syakir dan D.S. Effendi. 2010. Prospek Pengembangan Tanaman Aren (Arenga pinnata Merr) untuk Bioetanol, Peluang dan Tantangan. Makalah disajikan dalam Workshop Peluang, Tantangan dan Prospek Pengembangan Aren untuk 46 Volume 9 Nomor 1, Juni 2010 : 36 - 46 Bioetanol Skala Industri dan UMKM, Hotel Salak Bogor 21 Januari 2010. hlm.17. 
Vol.3, No.2. Agustus 2016. (18) : 170- 176 